\title{
Hugo? oui, Hugo!, anthologie de vers isolés recueillis et préfacés par Salath Stété
}

\section{Lise Sabourin}

\section{(2) OpenEdition}

10 Journals

\section{Édition électronique}

URL : http://journals.openedition.org/studifrancesi/33422

DOI : 10.4000/studifrancesi.33422

ISSN : 2421-5856

Éditeur

Rosenberg \& Sellier

\section{Édition imprimée}

Date de publication : 1 décembre 2005

Pagination : 662-663

ISSN : 0039-2944

\section{Référence électronique}

Lise Sabourin, «Hugo? oui, Hugo!, anthologie de vers isolés recueillis et préfacés par Salath Stété », Studi Francesi [En ligne], 147 (XLX | III) | 2005, mis en ligne le 30 novembre 2015, consulté le 20 avril 2021. URL : http://journals.openedition.org/studifrancesi/33422 ; DOI : https://doi.org/10.4000/ studifrancesi.33422

Ce document a été généré automatiquement le 20 avril 2021.

\section{(c)}

Studi Francesi è distribuita con Licenza Creative Commons Attribuzione - Non commerciale - Non opere derivate 4.0 Internazionale. 


\title{
Hugo? oui, Hugo!, anthologie de vers isolés recueillis et préfacés par Salath Stété
}

\author{
Lise Sabourin
}

\section{RÉFÉRENCE}

Hugo? oui, Hugo!, anthologie de vers isolés recueillis et préfacés par SALATH STÉTÉ, Paris, Imprimerie nationale Éditions, 2001, pp. 39 (préface), non paginé pour la suite.

1 Le célèbre essayiste et poète libanais s'est proposé, à l'occasion du bicentenaire de la naissance du grand romantique, de procéder à une «lecture sélective» de l'œuvre poétique immense de Hugo, à la recherche du «plus pur carbone», du «diamant natif». Salah Stétié retient 251 vers, isolés pour «fulguration, tendresse, imagination pétrifiée et pétrifiante, humour et cocasserie, jeux de langue» de l'artiste magicien qui écrivait: «Dérangez ces rubis, et que trouvez-vous? Moi».

2 La préface, sous forme de dialogue imaginaire, discerne, sous «l'homme de tréteaux» dont la stature nationale de Hugo a figé l'image avec le temps, la «macération intime du cœur dans l'eau lustrale de mots revirginisés» (p. 9). Chez cet autre Balzac de la société $\mathrm{du} \mathrm{XIX}^{\mathrm{e}}$ siècle, la primauté $\mathrm{du}$ verbe trouve son accomplissement dans «l'incandescence» (p.26) de «joyaux», condensés de sagesse ou de pure peinture, scandés par l'alexandrin.

3 Témoignage d'une fascination ancienne - même si d'autres poètes, Nerval, Baudelaire, Mallarmé et Char, hantent encore davantage l'esprit de Stétié - cette anthologie creuse en fait les sillons de sa propre créativité, mais offre aussi aux lecteurs un «bouquet de pierres dures» du «tempétueux» Hugo que d'aucuns pourraient juger noyées dans son tourbillon lyrique. 